\title{
STRATEGI GURU PENDIDIKAN AGAMA ISLAM DALAM MENINGKATKAN KUALITAS SHALAT BERJAMAAH DI SDN 106162 MEDAN STATE KECAMATAN PERCUT SEI TUAN KABUPATEN DELI SERDANG
}

\author{
Nurtakyidah \\ Penulis adalah SDN 106162 Medan State Kecamatan Percut Sei Tuan Kabupaten \\ Deli Serdang
}

\begin{abstract}
In general, the purpose of this study is to describe the strategy of Islamic Education teachers in improving the quality of prayer in congregation at SDN 106162 Medan Estate Percut Sei Tuan District Deli Serdang Regency. The research findings based on the observation instruments, interviews and documentation studies showed that: First, the process of congregational prayer was carried out with the guidance and direction of the Islamic Education teachers. Second, the coordination between the headmaster, the Islamic Education Teachers, and students' parents in improving the quality of prayer in congregation at SDN 106162 Medan Estate Percut Sei Tuan District Deli Serdang Regency is through formal as well as informal meetings. Third, the approach used by the Islamic Education teachers in motivating students to improve the quality of prayer in congregation at SDN 106162 Medan Estate Percut Sei Tuan District Deli Serdang Regency is through religious, individual, and group approaches. Fourth, the obstacles and challenges faced by the Islamic Education teachers in improvingthe quality of prayer in congregation at SDN 106162 Medan Estate PercutSei Tuan District Deli Serdang Regency.
\end{abstract}

Keywords: Strategy, Islamic Education Teacher, Congregational Prayer

\section{PENDAHULUAN}

Dilihat dari segi fungsi atau tugasnya, guru berfungsi sebagai : pendidik, pengajar, pembimbing dan pelatih. Keseluruhan fungsi guru di atas, merupakan tuntutan pemerintah sebagai konsekuensi tanggung jawab guru. Terdapat banyak peraturan pemerintah dan Undang-Undang yang berkaitan dengan tugas dan tangung jawab guru tersebut. Diantara Undang-Undang dan Peraturan Pemerintah tersebut adalah tertuang dalam Undang-Undang Guru dan Dosen Nomor 14 tahun 2005 tentang guru dan dosen (UUGD) yang menyebutkan bahwa guru wajib memiliki kualifikasi akademik, kompetensi, sertifikat pendidik, sehat jasmani dan rohani, serta memiliki kemampuan untuk mewujudkan tujuan pendidikan nasional. Lebih dalam lagi, pada pasal 10 ayat (1) UUGD dan Pasal 28 ayat 3 PP 19 tahun 2005 tentang Standar Nasional Pendidikan (SNP) dijelaskan bahwa kompetensi guru yang dimaksud meliputi : (1) kompetensi pedagogik, (2) kompetensi kepribadian, (3) kompetensi 
profesional dan (4) kompetensi sosial. Semua peraturan tersebut mengarah kepada profesionalisme guru, yang berarti bahwa guru harus memiliki kemampuan sesuai dengan profesinya sebagai guru.

Pendidikan agama merupakan salah satu bidang studi yang dimasukkan dalam setiap kurikulum formal dari tingkat dasar hingga perguruan tinggi di Indonesia. Hal ini sejalan dengan tujuan pendidikan nasional yang terdapat dalam Undang-undang Sistem Pendidikan Nasional Nomor 20 tahun 2003 pasal 3 yang berbunyi : Pendidikan Nasional berfungsi mengembangkan kemampuan dan membentuk watak serta peradaban bangsa yang bermanfaat dalam rangka mencerdaskan kehidupan bangsa, bertujuan untuk berkembangnya potensi peserta didik agar menjadi manusia yang ber iman dan bertaqwa kepada Tuhan Yang Maha Esa, berakhlak mulia, sehat, berilmu, cakap, kreatif, mandiri, dan menjadi warga Negara yang demokratis serta bertanggung jawab. (UUSPN, 2006:8)

Pernyataan di atas menggambarkan bahwa proses pendidikan tidak hanya untuk membekali peserta didik agar menjadi insan yang cerdas dalam segi keilmuan saja, tetapi juga berakhak sehat dan mulia.

Al-Zuhaily (2004: 9) menjelaskan bahwa agama Islam mempunyai cara yang unik untuk membentuk umatnya menjadi insan yang berakhlak dan sehat yaitu dengan cara "shalat". Seorang Muslim yang selalu mengingat Allah swt melalui pelaksanaan ibadah shalat, maka akan terhindar dari perbuatan dosa besar dan perbuatan yang keji. Selama masih ingat kepada Allah yang Maha Kuasa, Maha Mendengar dan mengetahui semua hal yang kelihatan atau yang tersembunyi, seorang yang mengaku muslim seyogyanya tidak akan mudah melanggar larangan-Nya atau meninggalkan perintah-Nya. Kecuali karena dalam keadaan yang sangat terpaksa, khilaf atau terlupa/tidak sengaja, yang begitu ingat atau sadar ia akan segera taubat, dengan sangat menyesali perbuatanya yang salah, langsung meninggalkan yang dilarang dan melakukan yang diwajibkan, bahkan menggantikan yang harus dikerjakannya dengan yang lebih baik dan sempurna.

Abdu (2003: 94) menegaskan bahwa dalam kehidupan kita sehari-hari sedikit orang bisa khusyu' dalam shalatnya. "Shalat berjamaah akan membantu seseorang khusyu' dalam shalat", tidak hanya itu, pahala yang diperoleh dari shalat berjamaah itu lebih besar daripada shalat sendiri. Untuk menjaga kekhusyu'an shalat seseorang, maka sangat perlu kiranya membiasakan shalat dengan cara berjama'ah. Shalat 
berjama'ah juga dapat dijadikan sebagai motivasi untuk selalu berusaha khusyu' dalam shalatnya

Fenomena yang kelihatan pada saat sekarang ini adalah banyak umat Islam yang meninggalkan shalat berjamaah. Ummat Islam lebih mementingkan urusan duniawi sehingga terlupakan untuk melaksanakan shalat berjama'ah denngan berbagai alasannya masing-masing. Padahal dengan shalat berjamaah paling tidak mengandung hikmah : dapat membangun persatuan umat, memaklumatkan syi'ar Islam, mengikis kesenjangan sosial antara anggota masyarakat, memupuk semangat ukhuwah umat Islam dan masih banyak lagi. Maka tidak mengherankan bila umat Islam saat ini mudah dipecah belah, diadu domba oleh pihak-pihak yang tidak bertanggung jawab. Kemungkinan, salah satu penyebabnya adalah karena saat ini jarang ummat Islam mengindahkan shalat berjamaah, kalaupun ada, hanya segelintir orang saja yang mengikutinya.

Selain membiasakan shalat wajib berjama'ah bagi peserta didik di sekolah, juga sangat penting untuk membiasakan shalat sunnah yang dilakukan secara bersama-sama di sekolah bagi peserta didik seperti halnya shalat sunnah dhuha yang dilaksanakan secara bersama-sama. Karena banyak manfaat yang didapatkan dengan melaksanakan shalat sunnah Dhuha. Terlebih lagi, kegiatan pelaksanaan shalat sunnah berjama'ah tersebut dilaksanakan secara bersama=sama, sehingga akan menimbulkan motivasi yang tinggi bagi para peserta didik untuk selalu dan terbiasa melaksanakannya. Dapat dimungkinkan, jika kebiasaan ini dilaksanakan di sekolah akan juga nanti dapat dilaksanakan di rumah, walaupun tanpa pengawasan dari para guru.

Kegiatan shalat berjamaa'ah baik wajib maupun sunnah telah banyak diteliti oleh para peneliti sebelumnya. Hal ini menunjukkan bahwa terdapat semangat yang tinggi dari guru untuk meningkatkan kualitas pelaksanaan sholat berjama'ah di sekolah, baik sholat wajib maupun sunnah. Berbagai strategi dan pendekatan dilakukan oleh guru, khususnya guru Pendidikan Agama Islam untuk meningkatkan kualitas dan motivasi peserta didik dalam melaksanakan shalat berjamaah.

Wulansari meneliti tentang Peran guru PAI dalam Meningkatkan Kedisiplinan Shalat Siswa di Madrasah (Studi pada Siswa MTs di Kecamatan Giriwoyo kabupaten Wonogiri. Kajiannya dilatarbelakangi dunia modern yang ditandai oleh semakin hilangnya batas ruang dan waktu telah membuat kehidupan manusia semakin kompleks. Kesibukan ini seringkali menggoda manusia untuk melupakan Allah karena 
lupa berdo'a dan bersyukur kepada Allah. Studi pada penelitian ini dimaksudkan untuk menjawab permasalahan: (1) Bagaimana kedisiplinan shalat siswa di Madrasah Tsanawiyah Kecamatan Giriwoyo Kabupaten Wonogiri ? (2) bagaimana peran guru PAI dalam meningkatkan kedisiplinan shalat siswa di Madrasah Tsanawiyah Kecamatan Giriwoyo Kabupaten Wonogiri? Permasalahan tersebut dibahas melalui penelitian studi kasus dan menggunakan pendekatan kualitatif deskriptif. Datanya diperoleh dengan cara wawancara, observasi dan studi dokumentasi. Semua data dianalisis dengan cara reduksi data, display data atau sajian data dan verifikasi atau penyimpulan data.

Kajian ini menunjukkan bahwa keadaan kedisiplinan shalat siswa di M.Ts. Muhammadiyah Kecamatan Giriwoyo Kabupaten Wonogiri memiliki kualitas baik. Sebagaimana penilaian hasil observasi mencapai rata-rata 65,70\%. Adapun guru PAI berperan sebagai murabbi, mu'allim, dan muaddib dalam meningkatkan kedisiplinan shalat para siswa di Madrasah. Peranan guru PAI dijabarkan sebagai berikut: Guru PAI berperan penting mentransformasikan pengetahuan dan pengalamannya, guru PAI adalah sosok yang menjadi suri tauladan, sosok yang digugu dan ditiru, guru PAI berperan sebagai pembimbing, guru PAI berperan sebagai penegak disiplin dan guru PAI berperan sebagai evaluator. (Eni Wulansari, 2014)

Berdasarkan observasi awal, peneliti menemukan data bahwa di SDN 106162 Medan Estate Kecamatan Percut Sei Tuan Kabupaten Deli Serdang, telah diterapkan oleh guru Pendidikan Agama Islam pelaksanaan shalat berjamaah, yaitu shalat wajib zhuhur dan shalat sunnah dhuha yang dilaksanakan secara bersama-sama bagi seluruh siswa. Berbagai strategi dan pendekatan telah diterapkan oleh guru untuk meningkatkan kualitas sholat berjamaah peserta didik tersebut. Shalat adalah kebutuhan atau kewajiban individu (masing-masing peserta didik) sebagai umat Islam, tapi tidak semua peserta didik sadar akan pentingnya shalat, terutama shalat berjamaah.

Namun pada kenyataannya, terdapat sebagian peserta didik yang sulit diarahkan untuk shalat berjamaah dengan berbagai alasan, selain itu dari pihak lembaga masih belum ada kebijakan yang tegas bagi peserta didik yang tidak mengikuti shalat berjama'ah padahal hal semacam ini juga perlu dilatih agar peserta didik dapat terbiasa melaksanakannya, dan diberikan pengarahan-pengarahan tentang keutamaan, hikmah-hikmah shalat berjamaah agar pada akhirnya kesadaran mereka 
muncul dengan sendirinya. Disinilah peran aktif guru diperlukan dan dibutuhkan, bila guru diartikan sebagai orang dewasa yang bertanggung jawab memberikan pertolongan pada anak didik dalam perkembangan jasmanai dan rohaniyah, agar mencapai tingakat kedewasaan, serta mampu berdiri sendiri dalam memenuhi tugasnya sebagai hamba Allah SWT disamping ia mampu sebagaia mahluk sosial dan makhluk individu untuk meningkatkan pelaksaan shalat berjamaah.

\section{KAJIAN TEORETIK}

\section{Strategi Guru PAI}

Strategi guru PAI yang dijadikan fokus dalam penelitian ini adalah meliputi strategi yang dilaksanakan guru PAI dalam melaksanakan tugas profesinya sebagai guru. Terdapat empat tugas yang harus dilaksanakan guru dalam menjalankan profesinya yaitu sebagai pendidik, sebagai pengajar, sebagai pembimbing dan sebagai pelatih. Keseluruhan tugas (fungsi) guru tersebut saling mempengaruhi dan saling mendukung dalam keseharian pekerjaannya sebagai guru profesional. Karena itu, peneliti berasumsi bahwa ketika guru melaksanakan kegiatan yang berkaitan dengan shalat berjamaah kepada para siswa di lokasi penelitian ini, guru PAI melakukan empat tugas (fungsi) sekaligus. Hal ini dapat dilihat dari pelaksanaan shalat berjama'ah yang sangat memerlukan keempat fungsi guru tersebut.

Istilah strategi (strategy) berasal dari "kata benda" dan "kata kerja" dalam bahasa Yunani. Sebagai kata benda, strategos merupakan gabungan kata stratos (militer) dengan kata ago (memimpin). Sebagai kata kerja, stratego berarti merencanakan (to plan). Menurut Abdul Majid dalam bukunya yang berjudul Strategi Pembelajaran, mengutip definisi dari Mintzberg dan Waters (1983) bahwa strategi adalah pola umum tentang keputusan atau tindakan. Oleh karena itu, strategi merupakan suatu pola yang direncanakan dan ditetapkan secara sengaja untuk melakukan kegiatan atau tindakan. Strategi mencakup tujuan kegiatan, siapa yang terlibat, isi, proses, dan sarana penunjang kegiatan (Majid, 2003: 3-4).

Berdasarkan beberapa pendapat di atas, maka dapat disimpulkan bahwa strategi pembelajaran adalah cara-cara yang akan dipilih dan digunakan oleh seorang pengajar untuk menyampaikan materi pembelajaran sehingga akan memudahkan peserta didik menerima dan memahami materi pembelajaran, yang pada akhirnya tujuan pembelajaran dapat dikuasainya di akhir kegiatan belajar. 
Strategi Guru dalam meningkatkan pelaksanaan shalat berjama'ah yaitu sebagai berikut:

1. Mengidentifikasi serta menetapkan spesifikasi dan kualifikasi perubahan tingkah laku dan kepribadian anak didik sebagaimana yang diharapkan.

2. Memilih sistem pendekatan dan metode belajar mengajar.

3. Menetapkan norma-norma dan batasan minimal keberhasilan atau kreteria serta standar keberhasilan sehingga dapat dijadikan pedoman bagi guru.

(Ahmadi, 1997:5)

\section{Shalat Berjamaa'ah}

Shalat menurut bahasa adalah do'a (Muhammad, 2010: 145). Dengan kata lain mempunyai arti mengagungkan. Shalla-yushallu-shalatan adalah akar kata shalat yang berasal dari bahasa Arab yang berarti berdoa atau mendirikan shalat. Kata shalat, jamaknya adalah shalawat yang berarti menghadapkan segenap pikiran untuk bersujud, bersyukur, dan memohon bantuan (Rajab, 2011:91). Sedangkan shalat menurut istilah adalah ibadah yang terdiri dari perbuatan dan ucapan tertentu yang dimulai dengan takbir dan diakhiri dengan salam (Hasbiyallah, 2013: 175). Dalam melakukan shalat berarti beribadah kepada Allah menurut syarat-syarat yang telah ditentukan.

Menurut Sabiq (1973: 205) shalat ialah suatu ibadah yang terdiri dari perkataan-perkataan dan perbuatan-perbuatan tertentu yang dimulai dengan takbir bagi Allah SWT dan diakhiri dengan memberi salam. Perkataan tersebut berupa bacaanbacaan al-Qur'an, takbir, tasbih, dan doa. Sedangkan perbuatan yang dimaksud berupa gerakan- gerakan dalam shalat misalnya berdiri, ruku', sujud, duduk, dan gerakangerakan lain yang dilakukan dalam shalat. Kata jama'ah diambil dari kata al-ijtima" berarti kumpul (Abdurraziq, 2007: 66). Jama'ah berarti sejumlah orang yang dikumpulkan oleh satu tujuan ( Al-Qahthani, 2008: 19). Shalat jama'ah adalah shalat yang dikerjakan secara bersama-sama, sedikitnya dua orang, yaitu yang satu sebagai imam dan yang satu lagi sebagai makmum ( Ash-shilawy, 2009:122).

Berarti dalam shalat berjamaah ada sebuah ketergantungan shalat makmum kepada shalat imam berdasarkan syarat-syarat tertentu. Menurut Kamus Istilah Fiqih shalat jama'ah adalah shalat yang dikerjakan secara bersama-sama, salah seorang diantaranya sebagai imam dan yang lainnya sebagai makmum (Mujieb, 2002: 318). Shalat berjama'ah adalah beberapa perkataan dan perbuatan yang dimulai dengan takbir dan diakhiri dengan salam, dengan maksud untuk beribadah kepada Allah, 
menurut syarat- syarat yang sudah ditentukan dan pelaksanaannya dilakukan secara bersama-sama, salah seorang diantaranya sebagai imam dan yang lainnya sebagai makmum.

Terdapat sedikit perbedaan antara penelitian relevan di atas dengan penelitian yang sedang diteliti. Perbedaannya terletak pada fokus kajian yang diteliti. Jika pada penelitian relevan di atas difokuskan pada peran guru dalam membiasakan kegiatan keagamaan di sekolah untuk meningkatkan religiusitas siswa dan sekaligus membiasakan siswa untuk melaksanakan shalat berjamaah secara mandiri. Sedangkan penelitian yang sedang diteliti ini difokuskan secara umum pada strategi yang digunakan oleh guru PAI dalam peningkatan kualitas shalat berjamaah siswa di SDN 106162 Medan Estate Kecamatan Percut Sei Tuan Kabupaten Deli Serdang.

Adapun secara khusus, penelitian ini difokuskan pada empat hal yaitu : Pertama, proses shalat berjamaah siswa di SDN 106162 Medan Estate Kecamatan Percut Sei Tuan Kabupaten Deli Serdang. Kedua, koordinasi yang dilakukan Kepala Sekolah dengan guru PAI dalam meningkatkan kualitas shalat berjamaah siswa di SDN 106162 Medan Estate Kecamatan Percut Sei Tuan Kabupaten Deli Serdang. Ketiga, pendekatan yang digunakan oleh guru PAI dalam memotivasi siswa untuk meningkatkan kualitas shalat berjamaah di SDN 106162 Medan Estate Kecamatan Percut Sei Tuan Kabupaten Deli Serdang. Keempat, kendala dan hambatan yang dihadapi guru PAI dalam meningkatkan kualitas shalat berjamaah siswa di SDN 106162 Medan Estate Kecamatan Percut Sei Tuan Kabupaten Deli Serdang.

\section{METODOLOGI}

\section{A. Tempat dan Waktu Penelitian}

Penelitian ini berada di SDN 106162 Medan Estate. Bertempat di Jl. Pasar V Medan Estate Kecamatan Percut Sei Tuan Kabupaten Deli Serdang. Penelitian ini direncanakan berlangsung pada bulan Januari sampai dengan bulan Mei 2018. Sebelum dilakukan penelitian ini terlebih dahulu dilaksanakan studi pendahuluan sampai menulis laporan penelitian.

\section{B. Metode dan Prosedur Penelitian}

Metode penelitian yang digunakan dalam penelitian ini adalah Metode Kualitatif. Sedangkan pendekatan yang dipilih adalah Fenomenologi. Metode kualitatif dipilih dikarenakan peneliti berusaha mengeksplorasi secara mendalam data 
tentang "Strategi Guru PAI dalam Meningkatkan Kualitas Shalat Berjamaah di SDN 106162 Medan Estate Kecamatan Percut Sei Tuan Kabupaten Deli Serdang” secara maksimal dan alamiah. Fenomenologi digunakan dalam penelitian ini sebagai sebuah pendekatan, dikarenakan peneliti ingin berupaya menggali semaksimal mungkin fenomena kejadian yang ditampilkan oleh subjek dan informan penelitian sesuai dengan perilaku mereka. Sedangkan peneliti berupaya untuk berdiam diri mengamati perilaku mereka sesuai dengan persepsi dan situasi sosialnya.

Penelitian ini digunakan untuk memecahkan atau menjawab permasalahan yang sedang dihadapi pada situasi sekarang. Dilakukan dengan menempuh langkahlangkah menghimpun informasi pengumpulan data, klassifikasi dan analisa data, interpretasi, membuat kesimpulan dan laporan.'(Sukmadinata, 2007:76). Hal ini dilakukan dengan tujuan utama untuk membuat gambaran tentang sesuatu keadaan secara obyektif dalam suatu deskripsi situasi.

\section{Data dan Sumber Data}

Subjek penelitiannya yaitu guru PAI yang melaksanakan strategi dalam meningkatkan kualitas shalat berjamaah di SDN 106162 Medan Estate Kecamatan Percut Sei Tuan Kabupaten Deli Serdang, serta peserta didik yang ikut berpartisipasi (terlibat) dalam kegiatan pelaksanaan shalat berjama'ah. Peneliti menentukan subjek dalam penelitian ini yaitu dua orang guru PAI, tiga orang peserta didik yang mewakili setiap kelas dari kelas empat sampai dengan kelas enam di SDN 106162 Medan Estate Kecamatan Percut Sei Tuan Kabupaten Deli Serdang.

Sedangkan informan dalam penelitian ini adalah seorang Kepala Sekolah, enam orang wali kelas, tiga orang tua peserta didik. Informan ini merupakan orang yang mengetahui informasi tentang strategi yang digunakan guru PAI dalam meningkatkan kualitas shalat berjamaah di SDN 106162 Medan Estate Kecamatan Percut Sei Tuan Kabupaten Deli Serdang.

\section{Instrumen dan Strategi Pengumpulan Data}

Strategi utama yang digunakan dalam pengumpulan data penelitian ini yaitu : Pertama, pada fase perencanaan, strategi yang digunakan adalah studi dokumen atau telaah literatur. Strategi ini digunakan untuk memperoleh data yang berkaitan dengan konsep-konsep teoritik berkaitan dengan Strategi guru PAI dan pelaksanaan shalat 
berjamaah di SDN 106162 Medan Estate Kecamatan Percut Sei Tuan Kabupaten Deli Serdang. Kedua, fase pengumpulan data pokok penelitian, strategi pengumpul data yang digunakan adalah pengamatan dan wawancara, baik yang dilakukan secara terstruktur maupun non terstruktur. Ketiga, fase melengkapi data, strategi pengumpul data yang digunakan adalah wawancara terstruktur yang dilakukan secara mendalam. Selain menggunakan instrumen wawancara dan studi dokumentasi, peneliti juga menggunakan strategi dan instrumen observasi.

\section{E. Prosedur Analisis Data}

Dalam studi kualitatif, analisis data adalah sebuah proses sistematik yang bertujuan untuk menyeleksi, mengkategori, membanding, mensintesa, dan menginterpretasi data untuk membangun suatu gambaran komprehensif tentang fenomena yang sedang diteliti. Karena itu, sebagaimana dinyatakan Merriam (1988:127) analisis data merupakan proses memberi makna terhadap suatu data.

Menurut McMillan dan Schumacher (2001:463), proses analisa data kualitatif pada dasarnya berlangsung secara berulang (cyclical) dan terintegrasi ke dalam seluruh tahapan penelitian. Sesuai dengan konteksnya penelitian ini, peneliti mengadaptasi analisa data kualitatif sebagaimana disarankan oleh McMillan dan Schumacher (2001:476), yaitu: Inductive analysis dan Interim analysis.

\section{F. Pemeriksaan Keabsahan Data}

Untuk menjamin kesahihan dan keabsahan data, maka peneliti berupaya menggunakan metode pengecekan keabsahan temuan. Dalam penelitian ini, pemeriksaan keabsahan data didasarkan pada kriteria-kriteria untuk menjamin kepercayaan data yang diperoleh melalui penelitian. Menurut Moeloeng (2002: 324325) kriteria tersebut ada 4, yaitu: kredibilitas, keteralihan, kebergantungan, dan konfirmabilitas. Peneliti menggunakan seluruh metode tersebut untuk pengecekan keabsahan temuan.

\section{HASIL DAN PEMBAHASAN PENELITIAN}

1. Proses Shalat Berjamaah di SDN 106162 Medan Estate Kecamatan Percut Sei Tuan Kabupaten Deli Serdang.

Dilihat dari pelaksanaan shalat berjamaah di SDN 106162 Medan Estate Kecamatan Percut Sei Tuan Kabupaten Deli Serdang sebagaimana temuan data hasil 
penelitian menunjukkan bahwa terdapat beberapa hal yang dilakukan oleh guru Pendidikan Agama Islam sebelum dan ketika terjadinya proses shalat berjamaah yaitu :

Pertama, dalam setiap kegiatan belajar mengajar Pendidikan Agama Islam, guru Pendidikan Agama Islam selalu memberikan penegasan tentang pentingnya shalat berjamaah kepada para peserta didik dan hikmah yang terkandung bagi siapa-siapa saja yang dapat melaksanakan shalat berjamaah. Selain itu pula djelaskan tentang hal-hal yang berkaitan dengan shalat berjamaah, misalnya persiapan yang perlu ada sebelum shalat, baik persiapan fisik maupun mental. Persiapan fisik, misalnya hal-hal yang berkaitan dengan sarana dan pra sarana yang harus dibawa oleh setiap peserta didik sebagai kelengkapan fasilitas dalam shalat berjamaah, dikarenakan sarana di sekolah belum lengkap maka peserta didik secara mandiri harus membawa mukena, sarung dan peci atau lobe.

Peserta didik diharuskan berwhudu, dan juga harus menjauhkan diri dari halhal yang membatalkan shalat. Sedangkan persiapan mental berkaitan dengan tanggungjawab setiap muslim dan muslimah dalam pelaksanaan shalat berjamaah yang harus benar-benar mampu dilaksanakan sesuai dengan aturan yang terkandung dalam ajaran Islam. Setelah guru PAI memberikan penjelasan tentang shalat berjamaah, para peserta didik dilatih satu persatu secara praktis oleh guru dalam kegiatan pembelajaran PAI tersebut. Sehingga, dapat dipastikan oleh guru PAI seluruh peserta didik mampu melaksanakan secara mandiri dan berkualitas shalat berjamaah yang akan dilaksanakannya.

Kedua, ketika sudah masuk waktu shalat dhuha para peserta didik antri dan secara bergantian melaksanakan shalat dikarenakan sempitnya ruangan shalat. Kegiatan shalat dhuha dilaksanakan secara bergelombang dengan kapasitas dapat dipenuhi oleh tiga shaf makmum. Karena itu, guru PAI benar-benar membimbing para peserta didik agar tidak membuat keributan baik ketika mengambil air whudu maupun ketika shalat. Sebelum petugas iqamah memulai iqamahnya, terlebih dahulu guru PAI merapikan mukena dan sarung dan barisan shaf, baik perempuan maupun laki-laki sekaligus memberikan motivasi agar dapat melaksanakan shalat dhuha secara bersamasama dengan khusyu' dan tidak boleh main-main.

Berdasarkan hasil observasi, peneliti dapat menggambarkan bahwa pelaksanaan shalat zhuhur dengan pelaksanaan shalat dhuha menggunakan ruangan yang berbeda. Khusus pada waktu shalat zhuhur, peserta didik menggunakan ruangan kelas di lantai 
dua dikarenakan telah berakhirnya proses pembelajaran dan juga bekas ruangan perpustakaan di lantai satu. Masing-masing ruangan shalat tersebut dipantau dan diawasi oleh guru Pendidikan Agama Islam, sehingga dapat dipastikan peserta didik benar-benar telah siap melaksanakan shalat zhuhur berjamaah. Sedangkan ketika shalat dhuha berjamaah, peserta didik menggunakan ruangan yang berada di bekas ruangan perpustakaan, dikarenakan ruangan kelas di atas digunakan untuk pembelajaran.

Peneliti mengamati bahwa selama pelaksanaan ibadah shalat zhuhur berjamaah dan sholat sunnah dhuha, guru Pendidikan Agama Islam selalu mengawasi gerakan shalat dan bacaan shalat yang dilakukan oleh imam dan makmum dan sesekali menegur jika terdapat kesalahan yang diperbuat imam, baik kesalahan dalam gerakan shalat maupun bacaan shalatnya. Setelah selesainya pelaksanaan ibadah shalat, imam membaca do'a dan diaminkan oleh seluruh makmum, kemudian guru Pendidikan Agama Islam memberikan bimbingan dan arahan terutama mengenai hal-hal yang menyangkut kegiatan shalat berjamaah.

\section{Koordinasi yang dilakukan antara Kepala Sekolah dengan Guru Pendidikan} Agama Islam serta orangtua peserta didik dalam meningkatkan kualitas shalat berjamaah peserta didik di SDN 106162 Medan Estate Kecamatan Percut Sei Tuan Kabupaten Deli Serdang.

Temuan penelitian menunjukkkan bahwa telah adanya kerjasama yang baik dalam mendukung kegiatan shalat berjamaah di sekolah ini. Dukungan berasal dari Kepala Sekolah, Guru Pendidikan Agama Islam, Orang tua Peserta didik dan peserta didik itu sendiri. Bentuk dukungan yang diberikan disesuaikan dengan kapasitas kemampuan dan kewajiban personil yang memberikan dukungan tersebut. Hal ini dapat dilihat antara lain misalnya dukungan yang diberikan orang tua peserta didik adalah memberikan motivasi kepada peserta didik untuk selalu mengikuti shalat berjamaah di sekolah. Pemberian motivasi ini dibarengi dengan adanya partisipasi dan kepedulian orang tua untuk mengingatkan peserta didik agar senantiasa membawa perlengkapan shalatnya, seperti mukena, sarung dan peci.

Dukungan yang diberikan oleh Kepala Sekolah adalah berupa penyediaan fasilitas untuk menunjang kegiatan shalat berjamaah, antara lain memberikan kepercayaan kepada guru Pendidikan Agama Islam untuk menggunakan fasilitas bekas ruangan perpustakaan untuk ruangan shalat berjamaah. Selain itu pula membuat tempat 
untuk berwhudu dengan semua peralatannya. Dukungan yang paling berarti dan penting yang diberikan oleh Kepala Sekolah adalah senantiasa memberikan motivasi dan pennghargaan kepada seluruh peserta didik untuk melaksanakan shalat berjamaah dengan baik.

Dukungan yang diberikan oleh guru Pendidikan Agama Islam adalah berupa pelaksanaan tugasnya sebagai guru yakni menjadi : Pertama, sebagai Pengajar, dalam hal kegiatan shalat berjamaah, guru Pendidikan Agama Islam memberikan penjelasan materi dalam setiap kesempatan pembelajaran tentang hal-hal yang berkaitan dengan shalat berjamaah. Selain itu diberikan kegiatan praktek tentang hal-hal yang harus dilakukan dalam shalat berjamaah baik secara perorangan maupun kelompok.

Kedua, sebagai Pendidik, guru Pendidikan Agama Islam berupaya untuk merubah perilaku peserta didik dari perilaku yang tidak baik menjadi baik, misalnya sebelum melaksanakan shalat berjamaah di sekolah terdapat peserta didik yang cenderung kurang mampu bersosialisasi dengan sesama temannya, setelah melaksanakan shalat berjamaah mereka mampu membina silaturrahim dengan sesama temannya, saling membantu, saling menghargai, saling menyayangi dan mengasihi dan sifat-sifat baik lainnya. Semakin banyak didikan yang diberikan guru Pendidikan Agama Islam dalam kegiatan shalat berjamaah, maka semakin tampak perubahan perilaku para peserta didik.

Ketiga, dalam tugasnya sebagai pembimbing, maka guru Pendidikan Agama Islam selalu memberikan bimbingan dan arahan tentang pentingnya shalat berjamaah serta pahala yang akan diperoleh bagi orang yang selalu mengamalkannya. Bimbingan dan arahan yang diberikan oleh guru Pendidikan Agama Islam tersebut dilaksanakan pada saat jam belajar berlangsung maupun di saat sebelum dan sesudah dilaksanakannya shalat berjamaah.

Keempat, guru Pendidikan Agama Islam sebagai seorang pelatih yang selalu melatih para peserta didik untuk benar-benar mampu mengerjakan shalat berjamaah. Disamping itu pula, kepercayaan berupa tugas menjadi imam, dan iqamah yang diberikan oleh guru Pendidikan Agama Islam merupakan bukti dari adanya latihan yang diberikan oleh guru PAI sebagai bentuk manifestasi tugasnya sebagai Pelatih. Latihan yang diberikan dilaksanakan pada saat jam pelajaran Pendidikan Agama Islam atau juga khusus ketika sebelum melaksanakan shalat berjamaah. 
Dukungan yang tidak kalah pentingnya dalam kegiatan shalat berjamaah adalah adanya kemauan dari peserta didik yang beragama Islam untuk ikut melaksanakan shalat berjamaah. Hal inilah yang membuat para guru PAI dan Kepala Sekolah khususnya merasa bersemangat untuk selalu membimbing, mengarahkan dan melatih mereka sehingga mampu melaksanakan shalat berjamaah dan akan meningkatkan kualitas shalat berjamaah mereka.

Koordinasi antara Kepala Sekolah, guru Pendidikan Agama Islam dan orang tua peserta didik juga dilakukan dalam setiap ada pertemuan dengan orang tua yang biasanya dilakukan secara formal dalam bentuk rapat awal tahun ajaran dan menjelang akhir tahun ajaran. Selain rapat yang dilaksanakan secara formal tersebut, terdapat juga kegiatan dalam bentuk perkumpulan antar orangtua dengan pihak sekolah yang bernama paguyuban. Paguyuban dilaksanakan selama sebulan sekali dengan mengumpukan seluruh orangtua peserta didik untuk membicarakan seluruh permasalahan yang berkaitan dengan kegiatan pendidikan anak-anak mereka di sekolah, termasuk di dalamnya kegiatan shalat berjamaah. Kegiatan paguyuban lebih intens dilakukkan dibandingkan kegiatan komite sekolah, karena kegiatan ini lebih bersifat kekeluargaan dan persaudaraan.

\section{Pendekatan yang digunakan oleh guru Pendidikan Agama Islam (PAI) dalam memotivasi peserta didik untuk meningkatkan kualitas shalat berjamaah di SDN 106162 Medan Estate Kecamatan Percut Sei Tuan Kabupaten Deli Serdang.}

Temuan hasil penelitian menunjukkan bahwa terdapat tiga pendekatan yang dilakukan oleh Guru Pendidikan Agama Islam dalam upaya untuk meningkatkan kualitas shalat berjamaah. Pendekatan tersebut dimaksudkan untuk memotivasi peserta didik agar mampu melaksanakan shalat berjamaah di sekolah secara baik. Pendekatan tersebut meliputi : Pertama, pendekatan agamis. Pendekatan ini berkaitan dengan usaha guru Pendidikan Agama Islam dalam menggugah kesadaran peserta didik untuk menyadari akan pentingnya shalat berjamaah, baik untuk dirinya maupun untuk masyarakat di sekitarnya. Bentuk pendekatan agamis berupa penjelasan dan pengarahan dari guru PAI tentang hal-hal yang berkaitan dengan shalat berjamaah dari sudut pandang ajaran Islam. 
Termasuk di dalamnya adalah penjelasan mengenai dalil-dalil yang memerintahkan untuk melaksanakan shalat berjamaah serta pahala yang akan diterima orang yang melaksanakan shalat berjamaah. Disamping itu pula, guru PAI menegaskan bahwa terdapat hikmah yang terkandung dalam shalat berjamaah, terutama terbentuknya rasa persaudaraan di antara sesama Muslim, dalam hal ini terbentuknya rasa persaudaraan diantara sesama peserta didik. Selain itu pula, peserta didik akan merasakan kenyamanan, ketenangan, dan ketenteraman setelah melaksanakan shalat berjamaah. Apalagi jika kegiatan shalat berjamaah dapat dijadikan sebagai rutinitas kegiatan shalat dalam kesehariannya. Bimbingan dan arahan yang merupakan manifestasi dari pendekatan agamis yang diberikan guru PAI tersebut dilaksanakan dalam setiap kesempatan ketika pemberian materi pelajaran pendidikan agama Islam di kelas, walaupun materi pelajarannya tidak selalu menyangkut tentang shalat berjamaah. Hal ini menunjukkan bahwa adanya semangat dan tanggungjawab dari guru PAI dalam meningkatkan kualitas shalat berjamaah.

Tujuan akhir dari pendekatan agamis ini adalah untuk meningkatkan kesadaran dan kemauan peserta didik dalam melaksanakan shalat berjamaah. Terlihat adanya peningkatan kesadaran peserta didik tentang pentingnya pelaksanaan shalat berjamaah di sekolah ini. Hal ini ditunjang berdasarkan temuan data hasil penelitian bahwa adanya motivasi dari guru PAI secara berkesinambungan dan tak jenuh-jenuhnya dalam mengajak, membimbing, dan mengarahkan seluruh peserta didik untuk berpartsipasi dalam shalat berjamaah, walaupun memang pada awalnya guru PAI di sekolah ini merasa kesulitan dalam mengajak peserta didik untuk melaksanakan shalat berjamaah. Hal ini dikarenakan peserta didik belum membiasakan dirinya untuk selalu melaksanakan shalat berjamaah.

Lambat laun, tingkat kesadaran peserta didik bertambah dalam mengikuti shalat berjamaah, dilihat dari observasi yang peneliti lakukan ketika berlangsungnya proses shalat berjamaah ditanadai dengan adanya peningkatan jumlah peserta didik yang mengikutinya dari hari ke hari. Hanya terdapat beberapa orang peserta didik yang masih belum mau mengikuti shalat berjamaah dengan berbagai alasan yang kurang dapat dipertanggungjawabkan, walaupun guru PAI berusaha membujuk mereka.

Kedua, pendekatan individual. Pendekatan ini dilakukan oeh guru PAI dalam upaya peningkatan kualitas shalat berjamaah melalui kegiatan bimbingan dan praktek tentang tata cara melaksanakan shalat berjamaah. Pendekatan individual dipilih 
dikarenakan guru PAI di sekolah ini ingin melihat kemampuan seluruh peserta didik dalam melaksanakan shalat berjamaah. Kegiatan praktek shalat secara per-orangan dilakukan baik selama proses pembelajaran pendidikan agama Islam di kelas maupun pada waktu-waktu tertentu di luar proses pembelajaran pendidikan agama Islam. Kemampuan peserta didik secara per-orangan dituntut dalam shalat berjamaah dikarenakan pelaksanaan shalat merupakan kewajiban dan tanggungjwab pada setiap diri orang Islam. Kekurangmampuan peserta didik dalam melaksanakan shalat, baik kurang mampu dalam segi bacaan shalatnya maupun gerakan shalatnya maka akan berakibat pada hasil pelaksanaan shalatnya yang akan diterimanya dari Allah swt berupa dosa bukan pahala. Karena itu, guru PAI di sekolah ini sangat dituntut tanggungjawabnya dalam membimbing peserta didik untuk mempraktekkan tata cara shalat berjamaah sebelum dilaksanakannya shalat berjamaah.

Ketiga, Pendekatan Kelompok. Pendekatan ini dilakukan oleh guru PAI dalam meningkatkan kualitas shalat berjamaah dengan berorientasi pada kemampuan praktis peserta didik secara berkelompok. Kemampuan praktis melalui pendekatan kelompok diharapkan peserta didik mampu melaksanakan shalat berjamaah dengan baik. Di dalam shalat berjamaah akan ada pembagian tugas antara makmum dan imam. Imam sebagai pimpinan akan selalu diikuti gerak geriknya dalam shalat dan bacaan shalatnya. Karena itu, makmum dilarang untuk mendahului pekerjaan Imam. Namun, jika imam berbuat kesalahan dalam shalatnya, maka makmum dapat menegur imam dengan teguran yang diajarkan dalam Islam. Hal-hal seperti inilah yang dipraktekkan oleh peserta didik dengan adanya latihan secara terus menerus dari guru pendidikan agama Islam. Kegiatan ini juga dimaksudkan untuk meningkatkan kualitas shalat berjamaah, sehingga dapat dipastikan nantinya ketika berlangsungnya shalat berjamaah tidak ada lagi masalah yang muncul secara terus menerus tentang shalat berjamah.

\section{Kendala dan hambatan yang dihadapi guru Pendidikan Agama Islam dalam meningkatkan kualitas shalat berjamaah peserta didik di SDN 106162 Medan Estate Kecamatan Percut Sei Tuan Kabupaten Deli Serdang}

Hasil penelitian menunjukkan bahwa terdapat beberapa kendala dan hambatan yang dihadapi guru Pendidikan Agama Islam dalam meningkatkan kualitas shalat berjamaah peserta didik di SDN 106162 Medan Estate Kecamatan Percut Sei Tuan Kabupaten Deli Serdang, baik secara internal maupun eksternal. Secara internal, 
kendala dan hambatan tersebut berasal dari dalam diri peserta didik yang kurang mau mengikuti shalat berjamaah, walaupun setiap akan dilaksanakannya shalat berjamaah guru Pendidikan Agama Islam mengabsensi kehadiran peserta didik dan memberikan nilai bagi peserta didik yang melaksankan shalat berjamaah. Berdasarkan wawancara yang dilakukan dengan guru Pendidikan Agama Islam, para peserta didik kemungkinan sudah jenuh mengikuti seluruh mata pelajaran apalagi adanya keharusan untuk mengikuti shalat berjamaah sehingga mereka ingin cepat-cepat pulang ke rumah.

Secara eksternal kendala yang dihadapi oleh guru Pendidikan Agama Islam berasal dari sekolah berupa fasilitas yang ada untuk shalat berjamaah dan partisipasi orangtua peserta didik. Fasilitas yang kurang memadai untuk pelaksanaan ibadah shalat berjamaah merupakan kendala dan hambatan yang dihadapi guru Pendidikan Agama Islam dalam meningkatkan kualitas shalat berjamaah. Berkaitan dengan ruangan yang digunakan untuk shalat zhuhur berjamaah masih menggunakan ruangan kelas di lantai dua ketika pembelajaran telah selesai. Sedangkan untuk shalat dhuha bersama-sama masih menggunakan ruangan bekas perpustakaan lama yang hanya mampu ditempati peserta didik dalam dua shaf . Kemudian, banyaknya peserta didik yang antri untuk berwhudhu dan shalat berjamaah terkadang menyebabkan kendala dan hambatan dalam pelaksanaan pembelajaran karena shalat dhuha yang dilakukan bersama-sama pada saat pembelajaran sedang berlangsung dan diberi waktu hanya beberapa menit untuk shalat dhuha berjamaah pada setiap harinya.

Berdasarkan temuan penelitian di atas, peneliti dapat mengilustrasikan bahwa keseluruhan strategi yang digunakan guru Pendidikan Agama Islam dalam rangka peningkatan kualitas shalat berjamaah di SDN 106162 Medan Estate Kecamatan Percut Sei Tuan Kabupaten Deli Serdang sesuai dengan apa yang diungkapkan oleh Ahmadi (1997:5) bahwa terdapat tiga strategi yang digunakan untuk peningkatan shalat berjamaah yaitu : Pertama, mengidentifikasi serta menetapkan spesifikasi dan kualifikasi perubahan tingkah laku dan kepribadian anak didik sebagaimana yang diharapkan. Kedua, memilih sistem pendekatan dan metode belajar mengajar. Ketiga, menetapkan norma-norma dan batasan minimal keberhasilan atau kreteria serta standar keberhasilan sehingga dapat dijadikan pedoman bagi guru. 


\section{PENUTUP}

\section{A. Kesimpulan}

Berdasarkan temuan dan pembahasan hasil penelitian, peneliti menyimpulkan penelitian ini sebagai berikut :

1. Proses kegiatan shalat berjamaah di SDN 106162 Medan Estate Kecamatan Percut Sei Tuan Kabupaten Deli Serdang berjalan secara baik. Hal ini dapat disimpulkan berdasarkan temuan penelitian bahwa guru Pendidikan Agama Islam melaksanakan bimbingan, pengarahan dan latihan sebelum dan ketika pelaksanakan shalat berjamaah kepada peserta didik . Sehingga, kegiatan shalat berjamaah berlangsung sesuai dengan tujuan yang diharapkan.

2. Koordinasi yang dilakukan antara Kepala Sekolah dengan Guru Pendidikan Agama Islam serta orangtua peserta didik dalam meningkatkan kualitas shalat berjamaah di SDN 106162 Medan Estate Kecamatan Percut Sei Tuan Kabupaten Deli Serdang melalui kegiatan rapat berupa musyawarah yang dilakukan antara Kepala Sekolah, Guru Pendidikan Agam Islam dan Orangtua peserta ddik yang membicarakan mengenai hal-hal yang berkaitan dengan shalat berjamaah. Tujuan adanya koordinasi ini dalam rangka peningkatan kualitas shalat berjamaah peserta didik. Hasil dari rapat ini adalah terutama untuk menggugah partisipasi orangtua dalam memotivasi anaknya untuk mengikuti shalat berjamaah. Sedangkan koordnasi yang dilakukan oleh Kepala Sekolah dengan guru Pendidikan Agama Islam agar senantiasa berupaya meningkatkan kualitas shalat berjamaah di SDN 106162 Medan Estate Kecamatan Percut Sei Tuan Kabupaten Deli Serdang.

3. Pendekatan yang digunakan oleh guru Pendidikan Agama Islam dalam memotivasi peserta didik untuk meningkatan kualitas shalat berjamaah di SDN 106162 Medan Estate Kecamatan Percut Sei Tuan Kabupaten Deli Serdang adalah melalui pendekatan agamis, individual da kelompok.

4. Kendala dan hambatan yang dihadapi guru Pendidikan Agama Islam dalam meningkatkan kualitas shalat berjamaah peserta didik di SDN 106162 Medan Estate Kecamatan Percut Sei Tuan Kabupaten Deli Serdang meliputi kendala dan hambatan secara internal dan eksternal. Secara internal, hambatan dan kendalanya adalah masih belum adanya kesadaran sebahagian peserta didik untuk melaksanakan shalat berjamaah. Kemudian, secara eksternal hambatan dan kendalanya meliputi belum lengkapnya fasilitas sekolah dalam pelaksanaan shalat 
berjamaah, misalnya belum adanya ruangan khusus yang diperuntukkan untuk shalat berjamaah dan masih menggunakan ruangan yang digunakan juga sebagai ruangan pembelajaran dan juga ruangan bekas perpustakaan yang lama yang kurang menyahuti jumlah peserta didik yang akan melaksanakan shalat berjamaah di sekolah ini.

\section{B. Rekomendasi}

Terdapat beberapa saran yang diajukan peneliti terkait dengan temuan data hasil penelitian yang diarahkan kepada para pemangku kebijakan khusus yang berkaitan dengan fokus penelitian :

1. Kepala Sekolah, agar senantiasa memberikan motivasi kepada para guru Pendidikan Agama Islam dalam rangka peningkatan kualitas shalat berjamaah di SDN 106162 Medan Estate Kecamatan Percut Sei Tuan Kabupaten Deli Serdang. Motivasi tersebut dapat dilakukan melalui pemberian bimbingan dan arahan tentang shalat berjamaah dan juga dapat dilakukan melalui adanya pemberian reward dalam bentuk pemberian penghargaan kepada para guru Pendidikan Agama Islam, baik secara material maupun non material.

2. Guru Pendidikan Agama Islam, agar senantiasa memberikan motivasi kepada seluruh peserta didik melalui bimbingan, pengarahan, latihan, dan pemberian reward kepada peserta didik. Bimbingan, pengarahan dan pemberian penghargaan tersebut sebagai upaya untuk meningkatkan kualitas shalat berjamaah.

3. Orangtua peserta didik, agar senantiasa memberikan partisipasinya untuk peningkatan kualitas shalat berjamaah dalam bentuk dukungan yang diberikannya kepada anak-anaknya untuk selalu mengikuti shalat berjamaah. Dukungan yang dapat diberikan orangtua dapat berupa selalu mengingatkan peserta didik sebelum berangkat ke sekolah untuk selalu mengikuti shalat berjamaah di sekolah disertai dengan menyediakan fasilitas perlengkapan alat shalat yang akan dibawa peserta didik ke sekolah.

4. Peserta didik, agar senantiasa benar-benar mampu dan mau melaksanakan shalat berjamaah. Kemampuan dan kemauan tersebut paling tidak bukan merupakan paksanaan dari orang lain, misalnya pihak sekolah maupun orangtua atau temannya, tetapi berdasarkan adanya kesadaran secara pribadi dan mandiri dari masing-masing peserta didik untuk selalu melaksanakan shalat berjamaah. 


\section{DAFTAR PUSTAKA}

Ahmadi, Abu dan Joko Tri Prasetya. Stategi Belajar Mengajar. Bandung: Pustaka setia. 1997

Ahmad, Abu dan Cholid Narbuko, Metodologi Penelitian. Jakarta ;Bumi Aksara 2001

Abdurraziq, Mahir Manshur, Mukjizat Shalat Berjama"ah, terj. Abdul Majid Alimin. Mitra Pustaka: Yogyakarta, 2007

Al-Zuhaily. Wahbah, Fiqih Shalat: Kajian Berbagai Madzhab Bandung: Pustaka Media Utama. 2004

Al-Qahthani, Said bin Ali bin Wahf, Lebih Berkah Dengan Sholat Berjamaah, terj. Muhammad bin Ibrahim. Qaula: Solo, 2008

Ash-shilawy, Ibnu Rifeah. Panduan Lengkap Ibadah Shalat. Citra Risalah: Yogyakarta. 2009

Atmowidjoyo, Sutardjo, Perencanaan Sistem Instruksional. Jakarta: Universitas Islam Jakarta. 2008

Departemen Agama RI, Al-Qu'an dan Terjemahnya. Jakarta: . Bumi Restu. 1974

Departemen Agama R.I. Al-Qur'an dan Terjemahnya. cet. 10, Jakarta: Proyek Pengadaan Kitab Suci Al-Qur'an Departemen Agama R.I. 2005

Depag RI. Al-Qur'an dan Terjemahnya. Semarang: Toha Putra. 1995

Hasbiyallah. Fiqh dan Ushul Fiqh. PT Remaja Rosdakarya: Bandung. 2013

Jauzi, Ibnu, Shahih Bukhori. Darul Hadits :Kairo. 2008

McMillan, James H., dan Sally Schumacher, Research in Education:A Conceptual Introduction. New York:Longman, 2001

Moleong, Lexy J. Metodologi Penelitian Kualitatif. Bandung: Remaja Rosda Karya. 2002

Majid, Abdul. Strategi Pembelajaran. Remaja Rosdakarya : Bandung. 2013

Miles, Mattehew B. dan Michael A. Huberman, Analisis Data Kualitatif. Edisi Indonesia terj. Rohidi, Tjetjep Rohendi. Jakarta: UI Press. 1992

Merriam, Sharan B. Case Study Research in Education: A Qualitative Approach. San Francisco: Jossy-Bass Publishers. 1988

Rajab, Khairunnas. Psikologi Ibadah. Amzah: Jakarta. 2010

Sabiq, Sayyid, Fikih Sunnah. Terj. Khairul dkk. Jakarta: Cakrawala Publising. 2008

Sabiq, Sayyid, Fikih Sunnah 1, terj. Mahyudin Syaf. Alma"earif: Bandung. 1973

Sanjaya,Wina, Strategi Pembelajaran Berorientasi Standar Proses Pendidikan, cet. 7. Jakarta: Kencana Prenada Media. 2010

Sanjaya, Wina, Strategi Pembelajaran Berorientasi Standar Proses Pendidikan. Jakarta: Kencana Prenada Media Group. 2007

Journalhomepage: ww.ejournal.almaata.ac.id/literasi

http://jurnalmahasiswa.unesa.ac.id/index.php/inspirasi-manajemen 